\title{
Низька теорія \\ (передмова до книжки «Квір-мистецтво неуспіху»)
}

\section{Яка є альтернатива?}

М і с т е р К р а б с: Тільки-но починаєш вірити, ніби знайшов землю молока та меду, а вони тебе хвать за штани, і смик догори, і тягнуть, усе тягнуть, i Т Я Г Н У Т b, аж висмикнуть із води, а ти сіпаєшся й засапуєшся. Тебе беруть і варять, а потім їдять, або й гірше!

Г у б к а Б о б (перелякано): Та що ж може бути гіршим?

М і с т е р К р а б с (м'яко): Сувенірна крамниця... «Сачок», «Губка Боб Квадратні Штани»

ільки-но починаєш вірити, ніби знайшов землю молока та меду, повчає Містер Крабс бідолашного старого Губку Боба Квадратні Штани, - і бац, виявляєш себе в меню або, ще гірше, в сувенірній крамниці, додатком до товару, аби надати йому настроєвости, з якою сам ти щойно розпрощався. Ми звикли, що наші мрії не справджуються, сподівання руйнуються, ілюзії розвіюються, але що приходить після сподівань? А раптом ми, мов той Губка Боб, віримо, що виправа до землі молока та меду не конче завершиться в сувенірній крамниці? Іншими словами, яка $є$ альтернатива, з одного боку, скептичній смиренності, а з іншого - простосердному оптимізму? Губка Боб хоче знати, яка є альтернатива цілоденній роботі на містера Крабса чи ризику бути впійманим у тенета товарного капіталізму, коли з цієї роботи тікатимеш? Ця книжка, як і «Правила життя Губки Боба Квадратні Штани», не плекає ідеалізму надії, а прагне здобути мудрість і новий, губчатий зв'язок із життям, культурою, знанням і насолодою.

Перекладено за виданням: Judith Halberstam, The Queer Art of Failure (Durham, London: Duke University Press, 2011), 1-25. Переклад здійснено в рамках проєкту HESP/ReSET «Гендер, сексуальність і влада» 3 дозволу Duke University Press.

(C) Марія Маєрчик, переклад, 2018

(C) Duke University Press, 2011

(c) Критика феміністична: східноєвропейський журнал феміністичних і квір-студій, 2018, № 1 http://feminist.krytyka.com 
Отже, яка є альтернатива? Це просте питання, оприявнюючи засадничі бажання жити по-іншому, започатковує новий політичний проєкт і проголошує пошук граматики можливостей (тут виявленої, зокрема, в герундіях і пасивних формах). Дослідники*1, активісти*, митці*, анімаційні персонажі* вже віддавна працюють над створенням альтернативних візій життя, любові та праці й над утіленням цих візій. У маніфестах, через розмаїті політичні тактики, за посередництвом нових технологій репрезентації радикальні утопісти* продовжують шукати інші способи буття у світі та взаємодії між собою - відмінні від визначених для ліберального та споживацького суб'єкта. В цій книжці я використаю «низьку теорію» (термін запозичено з робіт Стюарта Гола (Stuart Hall)) і популярні знання для вивчення альтернатив і пошуку шляхів в обхід звичних пасток і глухих кутів бінарних суджень. Низька теорія намагається виявити такі проміжні простори [in-between spaces], де ми убезпечені від гачків гегемонії чи спокус сувенірної крамниці. Але також вона визнає ймовірність, що альтернативи мешкають у каламутних водах парадоксів, часто нестерпно темних і негативних сферах критики та відмови. Тож книжка сновигає між високою та низькою культурою, високою та низькою теорією, популярною культурою й езотеричним знанням, аби подолати розмежування на життя й мистецтво, практику й теорію, думання й дію та вирватися в ще хаотичнішу сферу пізнання й незнайства.

У цій книжці я рухаюся від дитячих мультфільмів до авангардних перформансів і квір-мистецтва, щоб за їх допомоги думати про способи буття й пізнання поза конвенційним розумінням успіху. Я обстоюю думку, що в гетеронормативному капіталістичному суспільстві успіх легко ототожнюється зі специфічною формою репродуктивної зрілости в поєднанні з матеріяльним збагаченням. Але таке мірило успіху постало вимушено й не так давно: у зв'язку з крахом фінансового ринку, з одного боку, й небаченим зростанням кількости розлучень - з іншого. Якщо економічні буми та спади останніх років XX та початку XXI століть бодай чогось нас навчили, мусимо принаймні випрацювати здорову критику статичного розуміння успіху та невдач.

У книжці «Квір-мистецтво неуспіху» я обгрунтовую необхідність не так переглянути стандарт «склав* / не склав*», як зруйнувати саму логіку успіху та невдачі, таку типову для нашого суспільства. За певних обставин неуспіх, втрачання, забування, розбирання, руйнування, невідповідність, незнання можуть, зрештою, відкрити креативніші, взає-

\footnotetext{
${ }^{1}$ Зірочкою (*) в тексті позначено андроцентризми, яких не вдалося уникнути. В такий спосіб ми пропонуємо звертати увагу на ангажованість мови. Зірочку часто вживають на позначення трансґендерности (транс*). Проблематизуючи андроцентризми, ми водночас прагнемо виходити за межі бінарних ґендерних систем. - Прим. пер.
} 
модійніші [more cooperative], несподіваніші способи буття у світі. Бути неуспішними - це те, що квір-люди роблять і завжди робили винятково добре; для квір-людей неуспіх може бути стилем, згадаймо Квентина Криспа (Quentin Crisp), або способом життя, згадаймо Фуко (Foucault), і це засадничо відрізняється від безжального сценарію успіху, заснованого на принципі «пробувати знову й знову». Якщо успіх вимагає таких значних зусиль, то, можливо, в тривалій перспективі неуспіх є легшим шляхом, і він принесе інші винагороди.

Які винагороди може принести неуспіх? Найочевиднішою $є$ можливість уникнути каральних норм, які муштрують поведінку, скеровують розвиток людини, щоб від непокірного дитинства допровадити їі до слухняної та передбачуваної дорослости. Невдача залишає нам щось від чудесної анархії дитинства, розмиває чіткі, здавалося б, межі між дорослими та дітьми, переможцями* та невдахами. А позаяк невдачу неуникно супроводжують різні неґативні емоції - розчарування, втрата ілюзій, відчай, - вони також дають змогу підважити токсичну позитивність сьогодення. Барбара Еренрайх у книжці «На світлому боці» зауважує, що позитивне мислення $\epsilon$ північноамериканською недугою, «масовим потьмаренням», породженим із поєднання ідеї американської винятковости з бажанням вірити, буцім добрі люди неодмінно досягнуть успіху, а причина невдач - лиш у невмінні правильно налаштуватися й аж ніяк не в структурних передумовах (Ehrenreich 2009, 13). У США позитивне мислення пропоновано як засіб проти раку, як шлях до незліченних багатств, як надійний спосіб досягти особистого успіху. Власне, американці* радше охоче повірять, що успіх залежить від особистої налаштованости, ніж визнають, що їхній успіх визначають такі чинники, як раса, клас i ґендер. Еренрайх пише: «Якщо оптимізм є ключем до матеріяльного успіху, а оптимістичности можна досягти, вправляючись у позитивному мисленні, то неуспішним немає виправдання». Проте, продовжує вона, «іншим боком позитивности $є$ категорична вимога особистої відповідальности», себто, заки капіталізм продукує чийсь успіх коштом невдачі інших, ідеологія позитивного мислення стверджує, що для успіху треба важко працювати, а якщо ви зазнали невдачі - ви просто мало старалися (Ehrenreich 2009, 8). Аякже, скажемо ми тепер, коли банки, які обібрали простих людей, уважаються «закрутими для провалу» [too big to fail], а люди, яким не пощастило з іпотекою, - надто мізерними, щоб ними перейматися.

Еренрайх наводить приклад, як американські жінки намагаються подолати позитивним мисленням рак грудей, і показує, якою небезпечною буває віра в оптимізм і як люди готові завиграшки пристати на думку, що здоров'я залежить від особистої налаштованости, а не від забруднености довкілля, і що добробут забезпечують візуалізації успіху, а не сприятливі стартові умови. Однак невірам, які не сповідують культу позитивного мислення, - отим безталанним невдахам, вічно невдоволе- 
ним остогидлим скигліям*, які не хочуть «гарного дня» й не вірять, ніби рак робить їх ліпшими людьми, - політика пропонує кращий набір пояснень, ніж просто їхня особиста налаштованість. Адепти* негативного мислення мають явний зиск із неуспіху. Позбавлені обов'язку осяйно всміхатися під час хіміотерапії чи банкрутства, ці негативно налаштовані можуть скористатися своїм досвідом неуспіху, щоби запізнати кричущі нерівності американського повсякдення.

3 феміністичної перспективи невдача часто $є$ кращим варіянтом, аніж успіх. Коли жіночий успіх постійно вимірюють чоловічими стандартами, а ґендерний неуспіх нерідко означає послаблення вимоги відповідати патріярхальним ідеалам, неуспішність у фемінності може дати несподівану насолоду. В минулому на це по-різному вказували феміністки-відступниці. Монік Вітіг у 1970-х стверджувала: якщо фемінність $€$ продуктом гетеросексуальної системи, то лесбійки не $є$ «жінками», а якщо лесбійки не $\epsilon$ «жінками», то вони залишаються за рамками патріярхальних норм і можуть перевинайти деякі значення своїх гендерів (Wittig 1992). У тих-таки 1970-х Валері Соланас припустила: якщо «жінка» набуває значення лише в стосунку до «чоловіка», то слід «знищити чоловіків» (Solanas 2004, 72). Можливо, це звучить трохи різко, однак у кожному разі такі форми фемінізму, що їх у п'ятому розділі називаю похмурими фемінізмами, віддавна не давали спокою представницям м'якших форм фемінізму, орієнтованих на позитив, покращення й уподібнення, а не на негатив, відмову й трасформування. Похмурі фемінізми проявляються не через становлення, буття й створювання, а через непривітні й темні модуси руйнування, невідповідности та порушування.

Щоб розпочати розмову про невдачу, розгляньмо, як жіночий неуспіх відображено в популярних жанрах - до того ж це дуже повчально та цікаво. У фільмі «Маленька міс Щастя», що його режисирували Джонатан Дейтон і Валері Фарис («Little Miss Sunshine», 2006), дівчинка Олів Гувер у виконанні Ебігейл Бреслін затялася виграти в конкурсі юних красунь. Подорож героїні разом із ії дисфункційною родиною з Альбукерке до Південної Каліфорнії - найпереконливіша ілюстрація успіху та невдач, яку лиш можна уявити. В товаристві порнозалежного дідуся-наркомана, який ставив танцювальний номер Олів, і з командою підтримки в складі дядька-ґея із суїцидальними схильностями, заглибленого в читання Ніцше брата-мовчуна, честолюбного та верткого батька з підбадьорливими промовами, а також дратівливої мами-домогосподарки Олів була приречена на провал. На феєричний провал. I хоч їі програш міг стати джерелом страждань і принижень, та й зрештою став ним, він також емоційно викриває суперечливість суспільства, одержимого такими безглуздими змаганнями. Опосередковано фільм оприявнює й непевні моделі успіху, що за ними живуть і вмирають американські сім'ї. 
Майкл Арндт (Michael Arndt), який отримав «Оскар» за сценарій фільму, розповідав, що ідея сюжету виникла після публічної заяви губернатора Каліфорнії Арнольда Шварцнеґера: «Коли я когось і зневажаю, то це лузерів*!» Вочевидь, злегка фашизований Шварцнеґерів погляд на переможців* і переможених неабияк пришвидшив банкрутство його штату, а «Маленька міс Щастя» в багатьох сенсах передає погляд знизу, з перспективи невдах у світі, зацікавленому тільки в переможцях* Поразка Олів у конкурсі краси розгортається під пісню «Суперфрік»на сцені банального готелю в Редондо-Біч, під пильними поглядами повної зали супермам та їхніх доньок-«Джонбенет»². I ця поразка - кумедна за формою, гірка за змістом, утішна за вислідом - дає незмірно більше звільнення, а отже, $є$ незмірно ліпшою за всякий успіх, можливий у дитячому конкурсі краси. Олів крутить попою та роздягається під вульгарну пісню, поки надмірно нафарбовані й пишно зачесані ковґьорли та принцеси чекають напоготові, аби цнотливо прокружляти під софітами. Вона викриває, що справжнім мотивом конкурсів краси для дівчаток $\epsilon$ сексуальність. Не відкочуючись до пуританських нападок на сексуальну насолоду чи до моралізаторського осуду, «Маленька міс Щастя» відмовляється від дарвіністського гасла переможців* «Нехай переможе найкраща!» на користь неоанархістського кредо затятих невдах: «Ніхто не залишиться позаду!» Маленька дисфункційна родина, заскакуючи у свій пошарпаний жовтий бусик і вискакуючи з нього, тримається купи попри всі удари й прикрощі на шляху. І всупереч - або й завдяки - суїцидальним настроям, загрозі банкрутства, смерті родинного патріярха та цілковитій абсурдності конкурсу красунь народжується новий вид оптимізму. Це не оптимізм позитивного мислення, що виправдовує й уможливлює наявний суспільний лад, і не оптимізм, що за будь-яку ціну в усьому прагне знайти світлий бік. Це радше промінчик сонця, що дає порівну світла й тіні, знаючи: значення одного завжди узалежнено від значення іншого.

\section{Недисципліновані}

Нерозпізнаваність, отже, була та залишається надійною умовою для політичної автономности.

Джеймс Скот, «Бачити, як держава»

Книжка, яку розпочато цитуванням Губки Боба й підживлювано мудрістю з мультфільмів «Незрівнянний містер Фокс», «Втеча з курника», «У пошуках Немо» й інших анімованих життєвих посібників, ризикує

\footnotetext{
${ }^{2}$ Джонбенет Ремсі (1990-1996) - американська дівчинка «лялькової» зовнішности, учасниця конкурсів краси. Стала жертвою вбивства, досі не розкритого. Справа стала поштовхом до суспільної дискусії про дитячі конкурси краси й експлуатацію малолітніх. - Прим. ред.
} 
зажити слави несерйозної. Цього я й прагну. Коли нас сприймають серйозно, ми втрачаємо змогу бути легковажними, непристойними, нерелевантними. Са́ме прагнення здаватися серйозними змушує людей іти второваними й вивіреними шляхами у виробництві знань; натомість я хочу прокласти кілька кружних маршрутів. Ба більше, означення штибу серйозні та строгі є сигнальними для академічного та інших середовищ і свідчать про дисциплінарну коректність; вони $\epsilon$ ознакою такого типу вишколу й досліджень, коли за допомоги схвалених методів пізнання підтверджується заздалегідь відоме, а візіонерські осяяння та польоти уяви стають неможливими. Всякий вишкіл, зрештою, є відмовою від беньямінівської форми пізнання - бродити незвіданими дорогами в «хибному» керунку (Benjamin 1996); вишкіл є радше стоянням на добре освітленій території з чітким розумінням наперед, куди рухатись. Услід за своїми попередниками* я пропоную поставити собі за мету блукати й навіть бути готовими втратити більше, ніж тільки визначений шлях. Утрачати, погодьмося з поеткою Елізабет Бішоп, - це мистецтво, й «малою може виявитись втрата, / хай спершу буде крахом виглядати» (Bishop 2008, 166-167).

У царині точних наук, насамперед фізики та математики, є чимало ексцентричних інтелектуалів*, і не всі вони відлюдькуваті, як Унабомбер ${ }^{3}$ (хоч і такі трапляються). Вони забрідають на незвідані території та відмовляються від академічної науки, де принцип «публікуйся або помри» примушує їх до виробництва конвенційного знання та руху второваною доріжкою. Книжки з популярної математики смакують життєписами неординарних самітників*, які самоосвітою проклали власні шляхи крізь світ чисел. Таким дивакуватим умам дисциплінарні рамки заважають формулювати відповіді й теореми, бо пропонують готову схему ідей там, де інтуїція та пошук навпомацки дали б кращі результати. Наприклад, 2008 року в часописі «Нью-Йоркер*» було опубліковано історію ексцентричного фізика, який, подібно до інших амбітних фізиків* і математиків*, завзято винаходив велику теорію, «теорію всього». Цей мислитель, Гарет Лici (Garrett Lisi), відійшов від академічної фізики, де на той час панувала теорія струн, бо вважав, що істину слід шукати деінде. Лісі, пише Бенжамін Волес-Велс, «вибудував свою теорію, як це зміг зробити аутсайдер, із купи різних складників: саморобної математичної структури, незвичного опису гравітації та загадкової математичної категорії, відомої як $\mathrm{E}_{8} »^{4}$. I хоч «теорія всього» Лісі сподівань не ви-

\footnotetext{
3 Теодор Качинський (1942), прізвисько Унабомбер - американський математик, який, покинувши перспективну академічну кар'єру, впродовж двадцяти років розсилав поштою бомби людям, задіяним у високотехнологічних галузях і знищенні природних ресурсів. Засуджений до довічного ув'язнення в США. - Прим. ред.

${ }^{4}$ Wallace-Wells, Benjamin. «Surfing the University: An Academic Dropout and the Search for a Theory of Everything,» New Yorker, 21 July 2008: 33.
} 
правдала, вона породила цілу низку нових питань і методів. Аналогічно, як відомо з хроніки злету студії «Піксар», перші розробники* програм для створення CGI-графіки 5 були науковцями*, яких не прийняли в академію, або ж вони звільнилися самі заради втілення мрії про анімований світ, і створили окрему інституцію 6 . Такі альтернативні культурні й академічні світи, що існують радше поза академією, ніж усередині неї, такі інтелектуальні простори, що їх створили невдахи, переможені, вигнанці* та відмовники*, часто стають стартовими майданчиками для альтернативних проєктів, коли університети на це не спроможні.

Настав час експериментувати з трансформацією дисциплін задля проєкту виробництва нових форм знання, адже галузі, сформовані понад сторіччя тому на запит нової ринкової економіки та для потреб вузької фахової спеціялізації, як їх описував Фуко, нині втрачають актуальність і не в змозі відповідати ні сучасним науковим проєктам, ані студентським зацікавленням. Тепер, коли крупні дисципліни лускають, мов ті банки з невдалими інвестиціями, можна поставити питання руба: чи ми справді хочемо зміцнювати розтріпані границі наших спільних інтересів та інтелектуальних занять, а чи ліпше скористатися нагодою та переосмислити весь проєкт навчання й мислення? Так само, як стандартизовані тести в середніх школах США, що покликані визначати інтелектуальний рівень учнів*, насправді лише виявляють людей, здібних до складання стандартизованих іспитів (і аж ніяк не, скажімо, візіонерів*-розумах), в університетах оцінки, іспити, знання канону дають змогу виявити дослідників*, схильних підтримувати диктат дисципліни й пристосовуватися до нього.

Ця книжка пропонує мандрівку за межі конвенційного знання, в нерегульовані простори неуспіху, втрат і невідповідности, змушена далекими манівцями обходити рамки дисциплін і типові способи мислення. Я поясню, як університети (й, імовірно, старша школа) придушують замість підтримувати - неординарне, оригінальне мислення. Дисциплінарність, як писав Фуко (Foucault 1995), є технікою модерної влади: вона угрунтована на нормалізації, узвичаєннях, конвенціях, традиції та поширює їх, вона продукує фахівців* і адміністративні форми управління. Університетська структура, яка є оселею дисциплін і ревно боронить їхні кордони, нині опинилася на перехресті, але це не є перехрестя дисциплінарности та міждисциплінарности, минулого та майбутнього, національного і транснаціонального. Перехрестя, куди, стрімко розсипаючись, прибув потяг дисциплін, субдисциплін і міждисциплінарних ділянок, є роздоріжжям між університетом як корпорацією й об’єктом

\footnotetext{
${ }^{5}$ CGI - computer-generated imagery, буквально «зображення, згенеровані комп'ютером». - Прим. пер.

${ }^{6}$ Price, David A. The Pixar Touch. New York: Alfred A. Knopf, 2008.
} 
інвестування та університетом як новим типом публічної сфери з інвестиціями іншого штибу: в знання, ідеї, в мислення та політику.

Радикальний наступ на дисциплінарність і університет, що прогнозує водночас і розпад дисциплін, і зменшення розривів між традиційно розмежованими галузями, здійснили Фред Мотен і Стефано Гарні у своєму маніфесті «Університет і андеркомонс [undercommons]: сім тез», опублікованому 2004 року в часописі «Соціяльний текст» (Moten and Harney 2004). В есеї автори жорстко критикують інтелектуала* та критичного інтелектуала*, професійного дослідника* та «критичних академічних фахівців*». Для Мотена та Гарні критичний науковець* $\epsilon$ не відповіддю на наступ професіоналізації, але її продовженням, бо застосовує той самий інструментарій і леґітимаційні стратегії, аби стати «союзником* професійної освіти». Мотен і Гарні воліють ділити хліб із «підривними інтелектуалами*», спільнотою мислителів*-вигнанців*, які запротестували, відмовилися, відкинули вимоги «строгости», «майстерности» й «продуктивности». Вони кажуть нам «красти з університету», «красти просвіту для інших» (Moten and Harney 2004, 112) та протистояти «тому, що Фуко називав завоюванням, прихованою війною, яка заснувала й під тиском закону перезасновує суспільство» (Moten and Harney 2004, 113). Ким хочуть бути андеркомонс університету? Вони хочуть сформувати непрофесійну силу втеклих ерудитів*, чиї інтелектуальні заняття не буде прив'язано до системи іспитів і тестових балів. Метою такого знепрофесійнення $є$ не скасування; насправді Мотен і Гарні заохочують утеклих інтелектуалів не вилучати та скасовувати одне й засновувати та перезасновувати інше: «Не так скасування в'язниць, як скасування суспільства, в якому в'язниці $є$ можливими, в якому можливим $є$ рабство і можливою $є$ наймана праця, а отже, не скасування в значенні вилучення чогось, але скасування в значенні заснування нового суспільства» (Moten and Harney 2004, 113).

Не вилучати щось, а заснувати нове суспільство. Чом би й ні? Чом би не мислити категоріями суспільства іншого штибу - не того, яке спершу створило рабство, а потім його скасувало. Врешті-решт, багато мудрих людей говорили, що соціяльні світи, в яких ми живемо, є не єдино можливими; ці світи не були споконвіку наперед визначеними та безальтернативними; ба більше, під час постання цієї реальности чимало інших реальностей, ділянок знання та способів життя було відкинуто й, укотре цитуючи Фуко, «дискваліфіковано». Кілька візіонерських праць, написаних паралельно до дисциплінарного знання, показують ці знехтувані шляхи. Наприклад, Джеймс Скот у книжці «Бачити, як держава: кілька провальних спроб покращити умови людського життя» (Scott 1999) сам прокладає кружну дорогу, докладно описуючи, як модерна держава проїхалася катком по локальних, звичаєвих і позадисциплінарних формах знань, аби раціоналізувати й спростити соціяльні, сільсько- 
господарські та політичні практики з метою отримання прибутку. Як пише Скот, при цьому певні світоглядні позиції подавано як нормальні та природні, самоочевидні та неодмінні, хоча нерідко вони є вкрай суперечливими та соціяльно змодельованими. Він розпочинає книжку запитанням, «чому держава незмінно ворожа до “кочових людей"», однак швидко переходить до вивчення вимоги розпізнаваности, що її висуває держава, впроваджуючи систему стандартизації й уніфікації (Scott $1999,1)$. Дін Спейд та інші квір-дослідники* розмірковують на матеріялі Скотової книжки про те, як ми дійшли до повсюдної вимоги фіксувати ґендерну ідентичність у всіх офіційних документах (Spade 2008). Проте я хочу, грунтуючись на цій фундаментальній праці, виявити деякі відкинуті локальні знання, які було розтоптано стрімкою бюрократизацією та раціоналізацією економічного ладу, що ставить прибуток понад усіма іншими мотиваціями до життя й дії.

Організація регулярних німецьких лісопосадок править Скоту за переконливу метафору встановлення модерного бюрократичного контролю над населенням. Натомість ми зануримось у гущавину підкорених знань, що проростають бур'янами поміж дисциплінарних форм знання, повсякчас загрожуючи пересилити дбайливо вирощений і рівненько підстрижений інтелект своїм диким буянням. Для Скота «бачити, як держава» означає прийняти й інтерналізувати встановлений порядок речей, себто поділяти й відтворювати логіку вищости порядку, видаляти й навіть жертвувати інші, локальніші практичні знання, тим паче, коли вони менш ефективні й не такі ринкові, хоч у тривалій перспективі можуть виявитися надійнішими. Що поставлено на кін у виступах за дерева й проти лісу? Скот називає «розпізнаваність» головною метою високомодерних технологій сортування й упорядкування, що сприяють отриманню зиску із землі та людей і відділенню систем знань від локальних практичних знань. Автор пише про сад і садівників* як про представників* нового духу інтервенції та порядку, піднесених понад усе за високого модернізму. Він зауважує, що мінімалізм і спрощеність міського дизайну Ле Корбюзьє (Le Corbusier) є виявом нового прагнення до симетрії, поділу та планування, що доповнює авторитарне прагнення ієрархічности та зневажає складні, безладні форми природного буяння й імпровізаційної творчости. «Розпізнаваність, - пише Скот, умовою маніпулювання» (Scott 1999, 183). Натомість, звернувшись до европейської анархістської традиції, він надає перевагу практичнішим формам знань, що їх називає метис, де важать взаємність, колективність, гнучкість, розмаїтість і адаптивність. Власне, нерозпізнаваність може стати способом уникнути політичних маніпуляцій, яких зазнають усі університетські галузі та дисципліни.

Скотова ідея нерозпізнаваности застосовна до всіх груп суб’єктів, які зазнають маніпуляцій саме тоді, коли стають розпізнаваними, видими- 
ми для держави (працівники* без документів [undocumented workers] ${ }^{7}$, видимі квір-люди, расовані меншини), але також вона виступає на користь антидисциплінарности - в тому сенсі, що практики пізнання, що відкидають і форму, й зміст усталених канонів, можуть привести нас до несподіваних схем думання та модусів мислення, пов'язаних не зі строгістю й порядком, а з натхненням і непередбачуваністю. Можливо, ми хочемо поміркувати, що таке «бачити не як держава», хочемо мати нові мотивації для виробництва знань, інші естетичні стандарти впорядкування та розупорядкування простору, інші модуси політичної залучености - відмінні від надиктованих ліберальною уявою. Зрештою, ми можемо хотіти більше недисциплінованого знання, більше запитань і менше відповідей.

Дисципліни кваліфікують і дискваліфікують, легітимують і делегітимують, винагороджують і карають, а головне - вони стабільно самовідтворюються та придушують усяку незгоду. Фуко писав: «Дисципліни визначатимуть не кодекс закону, а кодекс нормалізації» (Foucault 2003, 38). У циклі лекцій про виробництво знання, виголошених у Колеж де Франс і виданих по смерті філософа збіркою «Суспільство треба захищати», Фуко окреслює контекст своїх антидисциплінарних міркувань і проголошує кінець доби «всеохопних і глобальних теорій», які поступилися місцем «локальному характеру критики» або «чомусь на зразок автономного та нецентралізованого теоретичного виробництва, чи, іншими словами, такому теоретичному виробництву, що для доведення власної цінности не потребує затвердження з боку загальних знань» (Foucault 2003, 6). Ці лекції Фуко читав у період написання першого тому «Історії сексуальности», де вже промальовується авторова критика репресивної влади (Foucault 1998); я ще повертатимуся до викладених у праці ідей про зворотний дискурс, надто щодо залучености сексуальних меншин у творення класифікаційних систем. Однак у збірці «Суспільство треба захищати» філософ зосереджується на академічній розпізнаваності й легітимації, описує й аналізує роль науковця* в обігу та відтворенні гегемонних структур.

Університети заохочують вивчати «всеохопні та глобальні теорії», натомість Фуко спонукає студентство звертати увагу на «підкорені знання», себто на ті форми виробництва знань, які було «поховано чи замасковано з потреб функціональної зв'язности або формальної систематизації» (Foucault 2003, 7). Такі форми знання було не просто втрачено чи забуто; їх було дискваліфіковано, визнано безглуздими, або неконцептуальними, або «недостатньо розробленими». Фуко називає їх «наївними знаннями, ієрархічно нижчими знаннями, знаннями,

\footnotetext{
${ }^{7}$ Ідеться про людей, які перебувають не в країні свого громадянства та працюють і живуть без документального оформлення. - Прим. пер.
} 
що перебувають нижче належного рівня ерудованости чи науковости» (Foucault 2003,7 ) - саме їх я називатиму знанням ізнизу.

Щодо виявлення «підкорених знань» можемо спитати себе: в який спосіб ми беремо участь у виробництві й обігу «підкорених знань»? Як ми утримуємо дисциплінарні форми знань на припоні? Як ми уникаємо таких «наукових» форм пізнання, що знецінюють інші модуси знань як буцімто зайві та невідповідні? Як ми навчаємо антидисциплінарного знання, як його застосовуємо? Фуко пропонує відповідь: «Правду кажучи, якщо ми боремося проти дисциплін, чи радше проти дисциплінарної влади, то в пошуках недисциплінарної влади нам не слід звертатися до старого права суверенітету; нам слід шукати нове право, що $€$ водночас антидисциплінарним і вільним від принципу суверенітету» (Foucault $2003,40)$. У певному сенсі ми маємо розучитися [untrain ourselves], аби знову побачити проблеми та полеміку в питаннях, які здавалися розв'язаними й закритими.

Заради такого проєкту й у дусі «Семи тез» Мотена та Гарні цю книжку я долучаю до руху «підривних інтелектуалів*», погоджуюся красти з університету, або, їхніми словами, «зловживати його гостинністю», i бути «в ньому, але не з ним» (Moten and Harney 2004, 101). Мотен і Гарні своїми тезами, поміж іншим, закликають «підривних інтелектуалів*» перейматись університетом, відкинути професіоналізацію, формувати колективізм і виходити в зовнішній світ, поза увиті плющем мури кампуса. Я додам до їхніх тез ще кілька. По-перше, опирайтеся експертності [resist mastery]. Тут варто наголосити на критиці «всеохопних і глобальних теорій», як їх означив Фуко. В моїй книжці цей супротив поставатиме як інвестиції в такі парадоксальні модуси знання, як невдача та глупство. Невдачу можемо тлумачити, скажімо, як відмову від експертности, як критику підсвідомо встановлюваного в межах капіталізму зв'язку між успіхом і вигодою, як контргегемонний дискурс програшу. Глупство апелює не просто до браку знань, а до обмежености певних форм пізнання та до певних способів опанування структур знання. Наприклад, по-справжньому творчі етнографічні дослідження базуються на незнайстві щодо інших. Розпочати етнографічний проєкт із визначеної мети, встановленого об'єкта дослідження та низки припущень означає унеможливити сам процес відкривання; це перешкоджатиме вивченню чогось, що виходить за наперед установлені рамки. Скажімо, в етнографічній розвідці про «ісламське відродження та феміністичний суб'єкт» у сучасному Єгипті (до неї я ще повернуся) Саба Махмуд пояснює, як мусила поступитися експертністю, аби вивчати деякі різновиди ісламізму. Вона пише: «Вживаючись у модуси пояснень, характерних для традиції, яку я колись засуджувала як неприйнятну, занурюючись у густу фактуру властивих їй почуттів і прихильностей, я зрештою зуміла підважити власні очікування та навіть почала осягати, чому іслам... справляє такий вплив на життя людей» (Mahmood 2005, 199). Авторка підсумовує свої 
міркування: «У войовничій зверхній атмосфері, де феміністична політика ризикує бути зведеною до плакатної риторики про ісламське насильство, ця спроба осягнення дає невеличку надію, що дослідження через діялог, а не експертність, може запропонувати ідею співіснування, яка не вимагатиме сприймати інші життєві світи як віджилі й тимчасові» (Mahmood 2005, 199). Розмова, а не експертність - справді виглядає на реальний спосіб буття у взаємодії з іншою формою буття, спосіб пізнання без намагань вимірювати інші життєві модальності стандартами ззовні.

По-друге: привілеюйте наївне та безсенсовне (глупство). Тут ми обстоюватимемо нездоровоглузде та неконцептуальне на противагу сенсотворчим структурам, які зазвичай вбудовано в загальновизнане розуміння етики. На ділі наївність або невігластво можуть вести до інших практик пізнання. Звісно, для цього потрібні так звані опозиційні педагогіки. У пошуку таких педагогік ми мусимо усвідомлювати, за формулюванням Ів Кософскі Седжвік, що невігластво $€$ «такою самою дієвою та складною річчю, як і знання» і що навчання часто відбувається зовсім незалежно від викладання (Sedgwick 1991, 4). Власне, якщо говорити про себе, то сумніваюся, чи я надаюся до навчання. Я ніколи не був відмінником, раз у раз безуспішно намагався опанувати іноземну мову, я можу майже нічого не запам'ятати з прочитаної книжки. Я усвідомлюю, що можу вивчити лише те, чого можу сам себе навчити, а чимало з того, чого мене вчили в школі, не залишило по собі й сліду. Питання нездатности до навчання порушено як політичну, навіть загальнонаціональну проблему в чудовому документальному фільмі «Клас» Лорана Канте («Entre Les Murs», Laurent Cantet, 2008), де показано рік життя однієї старшої школи в паризькому передмісті. Білий учитель Франсуа Бегадо (François Bégaudeau), на чиїх мемуарах засновано кінострічку, намагається зацікавити своїх байдужих, геть відчужених учнів*, здебільшого мігрантів* з Африки, Азії й арабських країн. Культурна, расова, класова відмінність між учителем і школярами* не додає продуктивности їхньому спілкуванню, вчителів культурний контекст («Щоденник Анни Франк», Мольєр і французька граматика) лишає учнів* незворушними. Водночас зацікавлення школярів*, як-от футбол, іслам і хіп-хоп, наражаються на дошкульні коментарі загалом стриманого чоловіка. В стилі документалістики Фредерика Вайсмана (Frederick Wiseman) дія фільму розгортається без усякого втручання «голосу згори», тож ми впритул спостерігаємо за гнівом і невдоволенням й учителя, й учнів*. Стрічку завершує промовиста сцена. Беґадо просить школярів* подумати, чого вони навчились, і записати щось одне, аби забрати із собою, - поняття, текст, ідею, які справили на них враження. Коли клас спорожнів, одна дівчина невпевнено підійшла до вчителя, той підвів погляд в очікуванні репліки. «Я нічого не навчилася, - сказала вона без злоби чи роздратування. - Нічого... Не можу згадати, чого навчилася». Момент поразки 
вчителя та розчарування глядача*, який прагне вірити в наратив освітнього зростання. Однак це й мить тріюмфу альтернативних педагогік, що нагадує нам: навчання є рухом назустріч одне одному, і неможливо чогось навчити без діялогічної взаємодії з учнем*.

Репліка «Я нічого не навчилася» може правити за ввідну до іншого французького тексту, книжки Жака Рансьєра про політику знання «Учитель-незнайко» (Rancière 1991). Автор розглядає способи обміну знаннями в обхід ідеї університету з його професорами* та студентами*, методами пояснень і стандартами досконалости, а натомість ратує за педагогіку іншого зразка, що передбачає та навіть вимагає рівности, а не ієрархічности. Рансьєр описує випадок із XVIII століття, коли один професор навчав французькою мовою бельгійських студентів*, які говорили тільки фламандською. На цьому прикладі Рансьєр показує, як конвенційна, дисципліноцентрична педагогіка вимагає неодмінного наставника, пропонуючи освітню модель, де студенти* просвіщаються вищим знанням, вишколом та інтелектом викладача*. Але досвід Жозефа Жакото з його брюсельськими студентами* показав, що його віра в необхідність тлумачень і екзегез була хибною, що так він просто підтримував університетську ієрархічну систему. Усвідомивши, що студентство й без його допомоги навчилося читати й писати французькою та подужало текст «Телемаха», Жакото відкрив нарцисичну суть своєї ролі. Він не був поганим викладачем, який став «добрим»; він був радше «добрим» викладачем, який збагнув: людей треба підвести до навчання, а не вчити наслідувати. Рансьєр іронічно коментує: «Як усі сумлінні викладачі, він знав, що учнів не можна натоптувати знаннями й змушувати зубрити, як папуг, але й потрібно уникати випадкових манівців, на яких губляться уми, що поки не здатні відрізнити суттєве від несуттєвого, засновок від наслідку» (Rancière 1991, 3) ${ }^{8}$. Заки «добрий» учитель* веде своїх студентів* дорогами раціональности, «вчитель*-незнайко» мусить дозволити їм заблукати, аби вони пережили невизначеність, а потім знайшли власний шлях назовні, або назад, або довкруж.

Автор «Учителя-незнайка» обстоює антидисциплінарний шлях емансипаційних форм знання, що не розраховують на вишколеного сопілкаря*, який виводить чемних дітей із темряви до світла. Жакото підсумовує свій погляд на педагогіку так: «Я мушу навчити вас того, що я не маю чого вас навчити» (Rancière 1991, 15). Так він дає іншим змогу навчати самих себе і здобувати знання без того, щоб засвоювати й інтерналізувати систему вищого та нижчого знання, вищого та нижчого інтелекту. Пауло Фрейре в праці «Педагогіка пригноблених» критикує «банківську» систему викладання та виступає за діялогічну модель навчання, що впроваджує практику свободи (Freire 2000). Так само Джа-

${ }^{8}$ Рансьєр Жак. Учитель-незнайко: п'ять уроків із розкріпачення розуму, пер. з фр. Андрія Рєпи, 18-19. Київ: Ніка-центр, 2013. - Прим. пер. 
кото, а за ним і Рансьєр, вказують на взаємозалежність між освітою та соціяльними трасформаціями. Якщо нас навчено, буцім ми знаємо щось лише тому, що нас цього навчили видатні уми, ми підкорилися цілому комплексу практик поневолення, які формують колоніяльний тип взаємодії (Freire 2000). Існує кілька можливих відповідей колоніяльним системам знань: жорстка відповідь, близька до заяви Франца Фанона (Frantz Fanon), що силове нав'язування колоніяльного ладу мусить наразитися на силовий опір; гомеопатична відповідь, коли суб'єкт пізнання вивчає домінантну систему глибше за її адептів* і підриває її зсередини; й негативна відповідь, коли суб'єкт відкидає пропоновані знання та відмовляється пізнавати в спосіб, продиктований просвітницькими філософіями себе та іншого*. В цій книжці я підтримую жорстку та неґативну форми антиколоніяльного пізнання та спираюся на ідею Мотена та Гарні про супротив університетові як місцю ув'язнених знань.

До проєкту про підкорені знання пропоную ще третю тезу: не довіряйте комеморації. Хоч яким слушним здається створення нових сховищ пам'яті про жертв гомофобії чи расизму, в багатьох сучасних текстах, художніх і наукових, автори* виступають проти комеморації. В «Улюбеній» Тоні Морісон (Morrison 1987), у мемуарах Сейдії Гартман «Утрать свою матір» (Hartman 2008), у роздумах Ейвері Гордон про забування та переслідування «Примарні справи» (Gordon 1996) - скрізь обстоювано думку, що через пам'ять відбувається стирання, бо комеморація схильна наводити лад у безладній історії (рабства, Голокосту, воєн тощо). Пам'ять як така є дисциплінарним механізмом - «ритуалом влади», як назвав її Фуко, вона визначає, що саме є важливим (історії тріюмфу), вона пропонує послідовний наратив у історії, що сповнена розривів і суперечностей, вона створює прецеденти для інших «комеморацій». У цій книжці способом опору героїчній гранд-логіці згадування стає забування, яке вивільняє нові форми пам'яті, угрунтовані радше на спектральності, ніж остаточних доказах, радше на втраті генеалогій, ніж спадкоємності, радше на викресленому, ніж вписаному.

\section{Низька теорія}

Ми припускаємося серйозної помилки, намагаючись «зчитувати» концепції, створені для оперування на високому рівні абстракцій, так, наче вони автоматично мають такий само теоретичний ефект на іншому, конкретнішому, «нижчому» рівні оперування.

Стюарт Гол, «Релевантність Грамші для студій раси й етнічности»

Спираючись на Рансьєрову ідею про інтелектуальну емансипацію, хочу запропонувати вам низьку теорію, себто теоретичне знання, що працює водночас на багатьох рівнях, мов одна з тих форм трансмісії, яка 
любить об'їзні шляхи, повороти й віражі крізь знання та спантеличення, яка прагне не роз'яснювати, а вплутувати. Отже, чим є низька теорія, куди веде нас і чому варто вкладатися в теорію, що, здається, радше посилює, ніж долає бінарність, у межах якої сама постає як інша в стосунку до високої теорії? Низька теорія - це спосіб думання, який висновую 3 відомого твердження Стюарта Гола про те, що теорія є не самоціллю, а «кружним шляхом до іншої цілі» (Hall 1991, 43). Повторюся, нам слід пам'ятати про вигоди від блукання порівняно з віднайденням власного шляху, тож пригадаймо беньямінівське бродіння та ситуаціоністський дрей $\oint^{9}$ [situationalist dérive] - мандрівку в несплановане, несподіване, імпровізоване та здатне дивувати. Поняття низька теорія я запозичив із міркувань Гола про ефективність Грамші (Gramsci) як мислителя. Відповідаючи на Альтюсерову (Althusser) заувагу, мовляв, тексти Грамші «недостатньо теоретизовані», Гол зазначає, що абстрактні принципи Грамші «було цілком однозначно створено для оперування на нижчих рівнях історичної конкретики» (Hall 1996, 413). Далі він стверджує, що Грамші «зовсім не цілив вище й не влучив у свою політичну ціль», а навпаки, як і сам Гол, він цілив нижче, аби охопити ширшу авдиторію. Тут можемо поміркувати про низьку теорію як форму загальнодоступности, але також можемо думати про неї як про теоретичну модель, яка оперує нижче рівня радару, скомпонована з ексцентричних текстів і прикладів, і яка відмовляється визнавати ієрархії знання, що підтримують високе у високій теорії ${ }^{10}$.

Доки існує явище, назване високою теорією - хай навіть вживано це поняття безсистемно чи як умовну назву певного напряму критичної думки, - доти потенційно існуватиме простір низької теорії; про це пише Гол в есеї «Релевантність Грамші для студій раси й етнічности». Він зауважує, що Грамші $є$ не «загальним теоретиком», а «політичним інтелектуалом і соціялістом - активістом італійської політичної сцени» (Hall 1996, 411). Для Гола це важить, тому що деякі теорії спрямовано на ціль саме в практичному, активістському сенсі; їх створено, аби формувати політичні практики, а не просто формулювати абстрактні ідеї заради нейтральних філософських проєктів. Упродовж цілого життя

\footnotetext{
9 Тут Галберстам апелює до ідей французького лівого радикала, філософа, історика, письменника, художника-аванґардиста та режисера Лі Дебора. Дрейф (фр. dérive) $\epsilon$ революційною стратегією, яку Лі Дебор описав у тексті «Теорія дрейфу» (1956). Автор - член організації «Ситуаціоністський інтернаціонал» - визначив дрейф як «форму експериментальної поведінки, пов'язаної з життям в урбанізованому суспільстві: техніку швидкого руху крізь різні середовища». - Прим. пер.

10 Девід Гребер у своїй книжці про анархізм теж розглядає «низьку теорію». Він пише: «Понад високу теорію анархізм потребує те, що можна назвати “низькою теорією”: способу давати раду з реальними, нагальними питаннями, що виникають у перебігу трансформативного проєкту» (Graeber 2004, 9). Гадаю, ми з Гребером мислимо в спільному керунку.
} 
Грамші належав до політичних партій і працював на різних політичних рівнях. Зрештою його ув'язнили за політичну діяльність, а невдовзі по звільненні з фашистської тюрми він помер.

Спираючись на образ Грамші як політичного мислителя, Гол доводить, що той ніколи не був марксистом у доктринальному, ортодоксальному чи релігійному сенсі. Як Беньямін i, власне, сам Гол, Грамші розумів, що неможливо слідувати марксистським текстам так, наче їх викарбувано в камені. Він вказує на історичні особливості політичних структур і пропонує брати під увагу ті нові обставини, що їх не могли передбачити й урахувати Маркс і марксизм. Для Беньяміна, Гола та Грамші ортодоксальність $\epsilon$ недозволенною розкішшю, навіть якщо йдеться про дотримання ортодоксальної лівої візії. Натомість, пише Гол, Грамші практикував справді «відкритий» марксизм, а відкритий марксизм, певна річ, - саме те, що Гол обстоює в «Марксизмі без ґарантій». Відкритий тут означає такий, що сумнівається, відкритий до несподіваних результатів, не зациклений на досягненні мети, невпевнений, адаптивний, змінний, гнучкий і налаштовуваний. «Відкрита» педагогіка в дусі Рансьєра та Фрейре теж відмежовується від директивних методик, незмінних логік і епістем; вона націлює нас на знання, скеровані на розв'язання проблем або на соціяльно чутливе розуміння радикальної справедливости.

Відповідно, поняття гегемонії, як його теоретизує Грамші й інтерпретує Гол, означує багаторівневу систему, за допомогою якої домінантна група встановлює владу не через примус, а через виробництво системи взаємопов'язаних ідей, яка переконує людей у правильності будь-якого встановленого набору ідей і поглядів, які нерідко є суперечливими. Грамші вживає термін здоровий глузд на позначення такого набору уявлень, які є переконливими саме тому, що їх не позиціоновано як ідеологію чи намагання домогтися згоди.

Для Грамші та Гола кожна людина бере участь в інтелектуальній діяльності - так само, як кожна готує їжу чи ладнає одяг і при цьому не мусить бути шеф-кухарем* або кравцем*. Розмежування традиційних і органічних інтелектуалів* $є$ важливим, бо виявляє напругу між інтелектуалами*, які беруть участь у становленні гегемонії (за допомоги як форми, так і змісту), та інтелектуалами*, які працюють з іншими, 3 класом у марксистському значенні, аби розібратися в суперечностях капіталізму й висвітлити опресивні форми влади [governance], якими пронизане повсякдення.

У сучасних університетах ми приділяємо значно більше уваги гегемонії, ніж контргегемонії. Під контргегемонією Грамші розумів, вочевидь, виробництво та поширення іншої, альтернативної системи ідей, що може стати частиною активної боротьби за зміну суспільства. Публікації про гегемонію надають їй стільки влади, що здається нереальним випрацювати контргегемонні практики. Проте Гол, услід за Грамші, під- 
тримує ідею освіти як популярної практики, спрямованої на культивування контргегемонних ідей і систем. Чималу частку своєї діяльности Гол присвятив Відкритому університету, виконуючи настанову, яку в своєму есеї приписав Грамші: він оперував «на різних рівнях абстракції».

I Гол, і Грамші не терпіли економізму. Це загальний принцип, приписуваний марксистській думці, який окреслює вкрай ригідну теоретичну взаємодію базису та надбудови. Як пояснив Альтюсер, «необхідною умовою виробництва $€$ [отже] відтворення умов виробництва»; іншими словами, щоб система працювала, вона має постійно створювати й підтримувати структури чи структуровані зв'язки, що дають їй змогу функціонувати (Althusser 2001, 85). Але це не є тотожним твердженню, що економічний базис визначає форму всіх решта соціяльних сил. Економізм, на думку Грамші та Гола, веде хіба що до примітивних моралізаторських суджень і аж ніяк не сприяє комплексному розумінню суспільних взаємин, що водночас і підтримують спосіб виробництва, і здатні його змінити. Низька теорія може закласти основи для контргегемонних форм теоретизування, створити теорію альтернатив у позадисциплінарному просторі виробництва знання.

\section{Піратські культури}

Що ж іще є кримінальним злочином, як не відчайдушний пошук альтернатив?

«Створюйте колективний зин», «Шахрзад» (Цюрих і Тегеран)

Чудовим взірцем низької теорії є фундаментальне історичне дослідження Пітера Лінебау та Маркуса Редикера про спротив капіталізму в XVII-XVIII століттях «Багатоголова гідра: матроси*, раби*, простолюд і прихована історія революційної Атлантики». В книжці простежено, за словами авторів, «боротьбу за альтернативні способи життя», що супроводжувала постання капіталізму на початку XVII століття й протистояла йому (Linebaugh and Rediker 2001, 15). На прикладах про піратство, виселення простолюду, міські бунти дослідники детально описують форми колоніяльного та національного насильства, що жорстко придушувало всяке заперечення проти влади середнього класу та знецінювало пролетарський опір як буцімто неорганізований, випадковий і аполітичний. Лінебау та Редикер відмовляються від звичного уявлення про ці рухи опору (як про начебто випадкові та позбавлені чіткої політичної мети), а натомість наголошують на силі внутрішньої співпраці антикапіталістичних ініціятив і приділяють особливу увагу альтернативам, що їх замислила й утілювала «багатоголова гідра» груп спротиву.

«Багатоголова гідра» $\epsilon$ визначальним текстом для будь-якої генеалогії альтернатив, адже його автори відкинули маскуліністський міт про геркулесівських капіталістичних героїв, які приборкують фемінну гідру 
некерованої анархії. Натомість вони розвертають цей міт до ії̈ багатьох голів, щоб отримати доступ до «переконливого спадку ймовірности», враховуючи справедливе застереження Гола: «Що ліпше ми розуміємо, як поставав капітал як такий, то ліпше розуміємо, що це лиш частина icторії» (Hall 1997, 180). У Лінебау та Редикера капітал постійно фігурує в наративах про спротив, ним викликаний, хай навіть ці рухи опору зрештою не досягли успіху в спробах зупинити розвиток капіталізму. Тож автори докладно описують різні спротиви, що на них наражався капіталізм наприкінці XVI століття: були там левелери* та діґери*, які виступали проти вилучення громадських земель чи суспільної власности; були й матроси*, заколотники* та потенційні раби*, які дорогою до Нового світу повставали проти капітанської влади та винаходили нові способи групових взаємин; були й релігійні дисиденти*, які вірили, що перед Богом усі рівні; а також багатонаціональні «змішані команди», які здіймали бунти на торговельних суднах, а потім курсували світом і розносили в різні порти звістку про повстання. Всі ці групи уособлюють тяглість протистояння, що відлунює донині. Лінебау та Редикер наповнюють конкретикою альтернативи, що їх виробили групи спротиву: про те, як жити, як думати про час і простір, як співмешкати в одному просторі з іншими, як проводити час поза логікою праці.

Історія альтернативних політичних формацій $\epsilon$ важливою, бо вона заперечує, що соціяльні стосунки є даністю, і дає змогу пізнати традиції політичної дії, хай не завжди успішні - в сенсі, що вони не стали панівними, - однак такі, що безумовно забезпечують взірці полемік, розриву та перервности для політичного сьогодення. Також ця історія виявляє потужні шляхи неуспіху, на ці неуспіхи ми можемо зіпертися в протистоянні логіці успіху, що виникла з тріюмфів глобального капіталізму. В «Багатоголовій гідрі» неуспіх $є$ мапою невзятих політичних доріг, проте він не позначає зовсім нових земель: дороги неуспіху - це весь проміжний простір між супермагістралями капіталу. I справді, Лінебау та Редикер не відкривають нових шляхів спротиву на основі нових архівів, вони використовують ті ж історичні джерела, на яких угрунтовано панівні наративи про піратів* як злочинців* і левелерів* як головорізів*, однак у тих самих записах церковних повчань і спогадах релігійних діячів* автори відчитують інші наративи про змагання й опір. На їхню думку, панівна історія сповнена слідами альтернативних можливостей, і завданням підривного інтелектуала* $є$ простежити обриси світів, що їх було створено й відкинуто.

Я спиратимуся не на архів історії пролетаріяту чи рухів пригнічених груп. Натомість я шукатиму низьку теорію та контрзнання у сфері популярної культури й у зв'язку з квір-життям, ґендером і сексуальністю. Зрештою, ґендер і сексуальність надто часто лишаються поза увагою фундаментальних досліджень альтернативних світів (зокрема й у Лінебау та Редикера). У «Квір-мистецтві неуспіху» я постійно - але не 
винятково - звертатимуся до «несерйозних» архівів [«silly» archives] анімаційного кіна. I хоча чимало читачів* можуть не погодитися з іде$€ ю$ що альтернативи можна знайти в жанрі, створеному крупними корпораціями заради великих прибутків і з численними товарними додатками, я вважаю, що нові форми анімації, зокрема CGI-графіка, відкрили нові наративні двері, які ведуть до несподіваного зближення дитячого, трасформативного та квірного. Науковці* й раніше відзначали неочікувані алегорії виробництва квір-знань в анімаційному кінематографі. Елізабет Фрімен на прикладі піксарівського фільму «Корпорація монстрів» викриває експлуатаційну суть неоліберального розуміння освіти, а також невисвітленість ґендеру та сексуальности в радикальній критиці неоліберального університету (Freeman 2005). Трактуючи «Корпорацію монстрів» як фільм про бажання, клас і навчальний простір, Фрімен підтримує нищівні закиди Біла Ридингса щодо неоліберальних університетських реформ (Readings 1997) і стверджує, що ця стрічка, яка є алегорією корпоративного видобування праці, «висвітлює соціяльні стосунки виробництва», навіть коли воно їх опосередковує (Freeman 2005, 90). Фрімен стверджує, що в повторюваних сценах зустрічі монстра* та дитини в спальні - за сюжетом, це мало спричиняти вереск, а вереск перетворювався на електроенергію для Монстрополіса, - йдеться про еротичний обмін, хоч і не названий прямо. За Фрімен, квірність цих зустрічей треба визнати бодай тому, що в іншому разі фільм зводиться просто до запропонованої в ньому гуманної заміни однієї форми експлуатації (видобування вереску) на іншу (видобування дитячого сміху). Лібідальна енергія обміну між монстром* і дитиною, як і лібідально заряджені стосунки між учителями* й учнями*, може бути здатною струснути самовдоволену систему. Фрімен пише: «Гуманітарні науки є струсом для здорового глузду, відрухом убік, який завжди робитиме наші дії незбагненними та непрогнозованими і який здатен вивільнити чи каталізувати вдосталь енергії, аби вибити частину інституційних запобіжників» (Freeman 2005, 93). Вона закликає вчителів* робити зі студентства монстрів* і підтримувати їх у процесі «непідконтрольних форм взаємодійности» (Freeman 2005, 94).

На відміну від Фрімен, я не заглиблююсь у дослідження лібідального обміну між учителем* і учнем*, тим паче, на мій погляд, такий підхід підтримує критиковану Рансьєром нарцисичну структуру освіти. Але, подібно до Фрімен, я глибоко вірю в педагогічний проєкт творення монстрів*, а також, як і вона, задля його втілення звертаюся до несерйозного архіву. Не все в цій книжці є легковажним, несерйозним або жартівливим, однак «несерйозний архів» - за безцінним висловом Лорен Берлант про «контрполітику несерйозного об'єкта» (Berlant 1997, 12) дає змогу сформувати запит на альтернативи, що суттєво відрізняється від запитів до архівів високої культури. Тексти, які я тут використовую, не роблять нас кращими людьми та не звільняють нас від культурної 
індустрії, проте вони можуть запропонувати незвичну антикапіталістичну логіку буття, дій і знання, й вони дадуть прихисток прихованим або явним квір-світам. Я справді вірю, що коли повільно раз по раз - у тверезому стані - переглядати фільм «Чувак, де моя тачка?», нам може відкритися таємниця всесвіту. I ще я вірю, що мультфільм «У пошуках Немо» містить таємний план світової революції, а «Втеча з курника»нарис феміністичної утопії для тих, хто вміє бачити більше, ніж пір'я та яйця. Я вірю в низьку теорію в популярній сфері, в малому, незначному, антимонументальному, в мікроскопічному, нерелевантному; я вірю, що ситуацію можна змінити на краще малими думками, коли поширювати їх великим світом. Я прагну провокувати, турбувати, набридати, дратувати й смішити; я роблю ставку на малі проєкти, мікрополітику, інтуїцію, примхи й ілюзії. Як Джесі та Честер із фільму «Чувак, де моя тачка?», я не парюся питанням, де я, в біса, припаркував машину; зате, як ті чуваки, просто мрію нафантазувати потенційно світоспасенні ідеї про життя на Урані абощо. I тут ви можете слушно запитати, як Іві в Гордона у «V означає Вендета» («V for Vendetta»): «Ти все зводиш до жартів?» На що дуже квірний і підривний ТБ-маестро відповів: «Нi, тільки те, що справді важить».

Анімаційні фільми, що становлять головну частину емпіричної бази цього дослідження, спираються на комічних і політично безконтрольних наслідках видового розмаїття; в них діють кури, щури, пінгвіни, лісові звірі, знову пінгвіни, риби, бджоли, собаки та мешканці* зоопарку. Власне, студії «Піксар» і «Дримворкс» у своїх роботах створили мультиплікаційний світ, багатий на політичні алегорії, сповнений квірности, щедрий на аналогії між людьми й тваринами. I хай творці цих фільмів відчайдушно стараються вкласти свої повідомлення в обгортку типових кліше («Будь собою», «Йди за своїми мріями», «Знайди споріднену душу»), водночас вони, як зазначає Фрімен у розвідці про «Корпорацію монстрів», доносять квірні та соціялістичні повідомлення, які часто корелюють між собою: «працюйте гуртом», «насолоджуйтесь інакшістю», «боріться з експлуатацією», «розвінчуйте ідеологію», «чиніть спротив».

Досліджуючи мультиплікацію - шлях знання, що може пролягати через популярну культуру, комп'ютерну графіку, історію й технології анімації, клітинну біологію, - ми досліджуємо, як влучно спостеріг Беньямін, класовані форми насолоди й технології культурної трансмісії. В одній із ранніх редакцій праці «Мистецький твір у добу своєї технічної відтворюваности» Беньямін відводить особливе місце новому анімаційному мистецтву Волта Диснея, що, на його думку, вивільняло щось на кшталт магічної свідомости масової авдиторії та витворювало утопічні простори й світи. Естер Леслі у своїй блискучій книжці «Голівудські рівнини», в розділі «Мікі Маус і утопія», писала: «Для Вальтера Беньяміна... мультфільми відображають реалістичну - але не натуралістичну картину обставин сучасного повсякдення; мультфільми показують, що 
навіть наші тіла нам не належать, ми відчужуємо їх в обмін на гроші чи віддаємо їхні частини у війні. Мультфільми демонструють, як те, що крокує під прапорами цивілізації, насправді є варварством. А людиноподібні тварини й оживлені предмети підводять до думки, що гуманізм $\epsilon$ не більше ніж ідеологією» (Leslie 2004, 83). На думку Леслі, Беньямін убачив у мультфільмах педагогічний потенціял, нагоду для дітей побачити зло, що ховається за фасадом буржуазної респектабельности, а для дорослих - відвоювати уявлення про чарівні можливості, що видавалися такими реальними в дитинстві: «Мультиплікаційний світ Диснея - це світ зубожілого досвіду, садизму та насильства. Іншими словами, це наш світ» (Leslie 2004, 83).

Ранні роботи Диснея, поруч із фільмами Чапліна, формували наратив засобами вайлуватих карикатур і уникали реалістичного мімезису. Персонажі розвалювалися на шматки й знову складалися докупи, вони вдавалися до трансформативного насильства, воліли залучати авдиторію радше через гумор, аніж трагедію. Проте, як зауважує Беньямін і наголошує Леслі, диснеївські мультфільми надто скоро перетворилися на буржуазний медіюм; вони швидко піддалися вимогам Bildung [нім. освіта, формування - пер.] і звелися до моралістичних казочок про гендерно нормативних і класово правильних героїв*, а в 1930-х стали улюбленим інструментом нацистської пропагандивної машини.

У сучасних творах комп'ютерної анімації теж є проривні сюжети, чарівні світи революції та трансформації, де діти, тварини й ляльки непередбачувано об’єднуються та повстають проти дорослих людей і безпринципних машин. Як у ранніх диснеївських мультфільмах, що заворожували та захоплювали Беньяміна, в ранніх роботах студій «Піксар» і «Дримворкс» колективну художню творчість поєднано з наративним світом анархії й антисімейними союзами персонажів*. Однак, як і в пізніх роботах Диснея, в пізніх фільмах «Піксара» - наприклад, «Волл-і» - наратив надії поєднано з наративом людськости, а критику буржуазного гуманізму підтримано рівно настільки, щоб гарантувати його повернення. Скажімо, роман Воллі $з$ айподоподібною «степфордською дружиною» Євою та його зусилля з повернення на Землю ожирілого людства зводять нанівець чудове заперечення товарного фетишизму на початку фільму: прочісуючи сміттєві завали на Землі в пошуках цінних об'єктів, Воллі байдуже викидає діямантові персні та дбайливо колекціонує оксамитові коробочки з-під них.

Лише кілька мейнстримних фільмів для дорослих, що їх споживає масова авдиторія, сміливо, відважно заступають на небезпечну територію революційної діяльности; в сучасній налаштованості на грубий буквалізм ризикованою здається навіть соціяльна сатира. У світі романтичних комедій і пригодницьких бойовиків не так багато нагод збочити в пошуках альтернатив. Наважуся стверджувати, що нині альтернативи можуть знайти прихисток лише в анімаційному кінематографі. Не- 
мультиплікаційні фільми, що користають із революційних і трансформативних тем, як-от «V означає Вендета» та «Люди Ікс» («The X Men»), засновано на коміксах і анімованих графічних романах. Як у наш час взаємопов'язані нові форми анімації й альтернативні політики? Чи може анімація підтримати утопічний проєкт тепер, якщо раніше, як нарікав Беньямін, не могла?

\section{Невдача як спосіб життя}

Вправляйтеся в поразках! Назва заходу феміністичної групи LTTR, 2004

У цій книжці про неуспіх я орієнтуюся на розуміння можливостей, яке прийнято вважати дитячим і незрілим; я шукаю альтернативи у формі того, що Фуко назвав «підкореним знанням» у нашій культурі, - в субкультурах, контркультурах і навіть у популярних культурах. Також я розвертаю значення неуспіху в іншому керунку, до групи емоційних модусів, які раніше асоціювалися з неуспіхом, але тепер знаменують нові напрями у квір-теорії. Я починаю з розгляду темного осердя негативу, породженого неуспіхом, переходжу від щасливих і продуктивних неуспіхів, вивчених на матеріялі анімації, до похмуріших сфер неуспіху, пов'язуваного з марнотою, безплідністю, спустошеністю, втратами, негативними почуттями загалом і станами невідповідности. Тож хоч у перших розділах я окреслюю значення неуспіху як способу буття у світі, в подальших розділах пропоную думку, що неуспіх є також небуттям, і ці модуси небуття й невідповідности припускають інший зв'язок зі знанням. У четвертому розділі я вивчаю значення мазохізму та пасивности у зв'язку з неуспіхом і фемінністю, а в шостому розділі відкидаю тріюмфалістську версію ґей-, лесбійської й трансґендерної історії, яка неминуче підтримує жорсткі принципи успішности і спадкоємности. Щоб освоїти суворі простори неуспіху, часом доводиться писати й визнавати темну історію, де суб’єкт співпрацює з пригноблювальними режимами й ідеологією домінування, а не послідовно протистоїть їм. Тож у шостому розділі я розглядаю дражливе питання взаємозв'язку між гомосексуальністю та фашизмом; я вважаю, що не можна нехтувати всіма даними про нацизм, що пов'язують його з ґей-маскулінізмом початку XX століття. Хоча в четвертому та п'ятому розділах ідеться про геть інші форми неуспіху, ніж у попередніх, присвячених анімації, мистецтву, глупству та забуванню, в цих перших частинах я теж заграю́ з темнішими формами неуспіху: зокрема в другому розділі, про втрачання та забування, й у подальших, про негативність, я продовжую міркувати над альтернативними інтерпретаціями втрати, мазохізму та пасивности.

Отже, це книжка про альтернативні шляхи пізнання та буття - не надто оптимістичні, проте й не застряглі в нігілістичному критикан- 
ському тупику. Це книжка про те, як зазнавати невдач удало, як бути неуспішним знову й знову, як навчитися, за словами Семюела Бекета (Samuel Beckett), бути ще неуспішнішими. Власне, з ідеєю неуспіху як практики я познайомився завдяки леґендарній лесбійській групі перформансисток LTTR. 2004 року вони запросили мене взяти участь у двох подіях - в Лос-Анджелесі та Нью-Йорку - під назвою «Вправляйтеся в поразках!», де зібралися квір- і феміністичні мислительки та перформансистки, щоби сформулювати, втілити й поширити нові значення неуспіху. На початку третього розділу, «Квір-мистецтво неуспіху», я описую цей захід і висловлюю вдячність учасницям LTTR за те, що виштовхнули мене на похмуру й химерну стежину неуспіху. Ця подія нагадала мені, що деякі найважливіші інтелектуальні прориви відбуваються незалежно від університетського вишколу та не внаслідок нього, кружними та паралельними шляхами поза уроками дисциплінарного мислення. Вона нагадала мені, що слід частіше зважуватися на ризик, на відчайдушні ідеї, уникати сварок, які видаються такими важливими для дисципліни, залучати ідеї, поширені в інших спільнотах. У цьому сенсі, сподіваюся, моя книжка буде зрозумілою широкій авдиторії, навіть якщо читацтво 3-поза академії вважатиме мої формулювання надто плутаними, а деякі науковці* вважатимуть мої аргументи надто очевидними. Не існує золотої середини між академічною та популярною авдиторією, проте, маю надію, мої численні приклади невдач накреслять мапу похмурих, темних, небезпечних територій неуспіху, що їх досліджуватиму.

Говорячи про дослідження та мапування, маю на увазі кружні шляхи та блукання. Згадаймо гасло з «Мадагаскару», ще одного дуже альтернативного мультфільму студії «Дримворкс»: «Губіться і не знаходьтеся!» У сиквелі «Мадагаскар: Втеча до Африки» (з підзаголовком «Досі загублені») зоопаркові втікачі* з першого фільму - зебра Марті, жираф Мелман, бегемотка Ґлорія та лев Алекс - намагаються дістатися додому, у Нью-Йорк, їм допомагають безумні пінгвіни та дивакуватий лемур. Чому тварини хочуть повернутися в неволю - лиш одне з багатьох екзистенційних питань, порушених у стрічці та мудро залишених без відповіді. (Ще одне питання - чому лемур хоче вкинути Мелмана в жерло вулкана, але його теж опустимо.) Так чи так, зоопаркові тварини вирушають додому літаком, що його пілотують пінгвіни, тож передбачувано зазнають катастрофи. По аварійній посадці тварини знову опиняються в «Африці», де возз'єднуються зі своїми стадами та зграями в «дикій» природі. Що могло бути нестерпно нудною притчею про родину, кревну подібність і природу, стало дивакуватою кошлатою левиною оповіддю про колективність, видове розмаїття, штучність і дискомфорт дому. Також це - опосередковано - алегоричний погляд на антидисциплінарне університетське життя: дехто з нас, хто втекли з кліток, можуть знову шукати шляхів назад, у зоопарк; інші, можливо, спробують відтворити резервацію в дикій природі, й лише жменька втікачів* уперто залиша- 
тимуться загубленими. Особисто я навіть не спромігся скласти вступні іспити до університету, про що мені недавно нагадав мій літній батько, й дотепер щосили опановую вміння лишатися загубленим. Заради такого кружного шляху обіч «правильного» знання кожен розділ цієї книжки губитиметься в хащах неуспіху, забування, глупства та заперечення. Ми будемо цікавитись, імпровізувати, збиватися на манівці та ходити колами. Ми втрачатимемо керунок, машини, план, можливо, ще й розум, але, блукаючи, знайдемо інші способи творити сенси, й тоді - повернімося до пошарпаного бусика з «Маленької міс Щастя»- ніхто не залишиться позаду.

Althusser, Louis. 2001. Lenin and Philosophy and Other Essays. New York: Monthly Review Press.

Benjamin, Walter. 1996. Selected Writings, Volume 1: 1913-1926, ed. Marcus Bullock and Michael W. Jennings. Cambridge: Harvard University Press.

Berlant, Lauren. 1997. The Queen of America Goes to Washington City: Essays on Sex and Citizenship. Durham: Duke University Press.

Bishop, Elizabeth. 2008. Elizabeth Bishop: Poems, Prose, and Letters, ed. Robert Giroux and Lloyd Schwartz. New York: Library of America.

Ehrenreich, Barbara. 2009. Bright-Sided: How the Relentless Pursuit of Positive Thinking Is Undermining America. New York: Metropolitan Books.

Foucault, Michel. 1998. The History of Sexuality, Vol. 1: An Introduction. New York: Vintage Books. Пер.: Фуко Мишель. Воля к истине: по ту сторону знания, власти и сексуальности. Пер. с фр., сост., комм. и послесл. С. Табачниковой. Москва: Касталь, 1996.

Foucault, Michel. 2003. Society Must Be Defended: Lectures at the Collège de France, 1975-1976, trans. David Macey. New York: Picador. Пер.: Фуко М. 2005. Нужно защищать общество: Курс лекций, прочитанных в Коллеж де Франс в 19751976 учебном году, пер. с фр. Е. Самарской. Санкт-Петербург: Наука.

Freire, Paulo. 2000. Pedagogy of the Oppressed, trans. Myra Bergman Ramos. New York: Continuum. Пер.: Фрейре Пауло. 2003. Педагогіка пригноблених, пер. 3 англ. О. Дем'янчук. Київ: Юніверс.

Freeman, Elizabeth. 2005. "Monsters, Inc. : Notes on the Neoliberal Arts Education." New Literary History 36 (1): 83-95.

Gordon, Avery F. 1996. Ghostly Matters: Haunting and the Sociological Imagination. Minneapolis: University of Minnesota Press.

Hall, Stuart. 1991. "Old and New Identities, Old and New Ethnicities." Culture, Globalization and the World System, ed. Anthony D. King, 42-69. London: Macmillan.

Hall, Stuart. 1996. "Gramsci's Relevance for the Study of Race and Ethnicity." Stuart Hall: Critical Dialogues in Cultural Studies, ed. Kuan-Hsing and David Morley Chen, 411-441. London and New York: Routledge.

Hartman, Saidiya. 2008. Lose Your Mother: A Journey Along the Atlantic Slave Route. New York: Farrar, Straus and Giroux.

Graeber, David. 2004. Fragments of an Anarchist Anthropology. Chicago: Prickly Paradigm Press.

Leslie, Esther. 2004. Hollywood Flatlands: Animation, Critical Theory and the AvantGarde. New York: Verso. 
Linebaugh, Peter, and Marcus Rediker. 2001. The Many-Headed Hydra: Sailors, Slaves, Commoners, and the Hidden History of the Revolutionary Atlantic. Boston: Beacon Press.

Mahmood, Saba. 2005. Politics of Piety: The Islamic Revival and the Feminist Subject. Princeton: Princeton University Press.

Morrison, Toni. 1987. Beloved. New York: Alfred A. Knopf.

Moten, Fred, and Stefano Harney. 2004. "The University and the Undercommons: Seven Theses." Social Text 22 (2): 101-15.

Rancière, Jacques. 1991. The Ignorant Schoolmaster: Five Lessons in Intellectual Emancipation, trans. Kirsten Ross. Palo Alto, Calif.: Stanford University Press. Пер.: Рансьєр Жак. 2013. Учитель-незнайко. П'ять уроків із розкріпачення розуму, пер. з фр. А. Рєпа. Київ: Ніка-Центр.

Readings, Bill. 1997. The University in Ruins. Cambridge: Harvard University Press.

Sedgwick, Eve Kosofsky. 1990. Epistemology of the Closet. Los Angeles: University of California Press.

Scott, James C. 1999. Seeing Like a State: How Certain Schemes to Improve the Human Condition Have Failed. New Haven: Yale University Press. Пер.: Скотт Дж. 2005. Благими намерениями государства. Почему и как проваливались проекты улучшения условий человеческой жизни, пер. с англ. Э. Гусинского, Ю. Турчаниновой. Москва: Университетская книга.

Solanas, Valerie. 2004. SCUM Manifesto. Introduction by Avital Ronell. New York: Verso. Spade, Dean. 2008. "Documenting Gender." Hastings Law Journal 59 (1): 731-842.

Wittig, Monique. 1992. The Straight Mind: And Other Essays. Boston: Beacon Press. 